\title{
La notion de représentation sous la Révolution française
}

\section{Pierre Brunet}

\section{(2) OpenEdition \\ 1 Journals}

Édition électronique

URL : https://journals.openedition.org/ahrf/592

DOI : 10.4000/ahrf.592

ISSN : 1952-403X

\section{Éditeur :}

Armand Colin, Société des études robespierristes

\section{Édition imprimée}

Date de publication : 1 juin 2002

Pagination : 27-45

ISSN : 0003-4436

\section{Référence électronique}

Pierre Brunet, "La notion de représentation sous la Révolution française », Annales historiques de la Révolution française [En ligne], 328 | avril-juin 2002, mis en ligne le 20 avril 2004, consulté le 24 avril 2022. URL : http://journals.openedition.org/ahrf/592 ; DOI : https://doi.org/10.4000/ahrf.592

Ce document a été généré automatiquement le 24 avril 2022.

Tous droits réservés 


\title{
La notion de représentation sous la Révolution française
}

\author{
Pierre Brunet
}

\section{RÉSUMÉS}

La notion de représentation sous la Révolution est plus difficile à saisir qu'on ne le croit parfois. Elle est d'ailleurs rarement analysée en tant que telle. Généralement appréhendée à travers la pratique parlementaire, on considère qu'elle trouve son origine dans l'élection que la Révolution tend à généraliser. Or, représenter ne signifie pas être élu mais produire un unité politique organisée c'est-à-dire hiérarchisée. Pour le comprendre, il faut revenir aux discours révolutionnaires en même temps qu'à leurs réalisations juridiques constitutionnelles.

The Notion of Representation during the French Revolution

The notion of representation during the French Revolution is harder to grasp than is sometimes thought. Moreover, it is rarely analysed as such. Generally addressed within the context of parliamentary practice, it is thought to stem from the elections which the Revolution tended to generalize. But to represent does not mean to be elected, rather to produce an organized, i. e. a hierarchical, political entity. In order to understand the process, it is necessary to reexamine revolutionary discourse and also the legal constitutional structures it generated.

\section{INDEX}

Mots-clés : élections, consentement, corps politique, État, hiérarchie, loi, organe, unité 